\title{
Multifunctional hydrolysates from kenaf (Hibiscus cannabinus L.) seed protein with high antihypertensive activity in vitro and in vivo
}

\begin{abstract}
Kenaf (Hibiscus cannabinus L.) seed is an underutilized protein-rich resource considered as a by-product of the kenaf fiber processing industry. Its high protein content (34\%) makes it a promising candidate as a source of bioactive protein hydrolysates. In this study, the potential of enzymatically hydrolyzed kenaf seed protein to generate multifunctional bioactive peptides was evaluated. Kenaf seed protein concentrate was hydrolyzed using four different proteolytic enzymes (papain, alcalase, bromelain, and flavourzyme) at their respective optimum $\mathrm{pH}$ and temperature. The choice of enzyme affected the bioactivities to a certain degree as KSPH were shown to possess high ACE inhibitory activity and low-to-moderate DPP-IV and antioxidant activity. Papain KSPH showed the highest ACE inhibitory activity with 95\% inhibition compared to other enzymatic hydrolysates, and therefore was chosen for further investigation of its antihypertensive activity. Papain KSPH was profiled for its hydrophobicity by RP-HPLC and revealed that the majority of late-eluting fractions exerted the highest ACE inhibitory activity. Spontaneously hypertensive rats showed a decrease of approximately $18-46 \mathrm{mmHg}$ in their systolic blood pressure (BP) from 0 to $24 \mathrm{~h}$ after oral administration of papain KSPH at dosages of $100 \mathrm{mg} / \mathrm{kg}, 300 \mathrm{mg} / \mathrm{kg}$, and $500 \mathrm{mg} / \mathrm{kg}$. However, the effect was not dosedependent. As a novel protein source, future research should aim to demonstrate the safety of kenaf seed protein and its hydrolysates, and validate its bioactivity through human intervention trials. Overall, kenaf seed protein has the potential to generate antihypertensive hydrolysates with multifunctional bioactivities as part of a functional food ingredient.
\end{abstract}

Keyword: Kenaf seed; Protein hydrolysate; Multifunctional bioactivity; Antihypertensive; Spontaneously hypertensive rat 